\title{
Study on Herbicidal Potential of Two Fungi in Qinghai Region
}

\author{
Liang Cheng1,2,3, Haixia Zhu'1,2,3, Youhai Wei1,2,3, Liangzhi Guo ${ }^{1,2,3}$, Hua Weng1,2,3, Qingyun Guo 1,2,3* \\ ${ }^{1}$ Academy of Agriculture and Forestry Sciences, Qinghai University, Xining, China \\ ${ }^{2}$ Key Laboratory of Agricultural Integrated Pest Management in Qinghai Province, Xining, China \\ ${ }^{3}$ Scientifc Observing and Experimental Station of Crop Pests in Xining, Ministry of Agriculture and Rural Affairs, Xining, China \\ Email: *guoqingyunqh@163.com
}

How to cite this paper: Cheng, L., Zhu, H.X., Wei, Y.H., Guo, L.Z., Weng, H. and Guo, Q.Y. (2022) Study on Herbicidal Potential of Two Fungi in Qinghai Region. Open Access Library Journal, 9: e8294. https://doi.org/10.4236/oalib.1108294

Received: December 13, 2021

Accepted: January 11, 2022

Published: January 14, 2022

Copyright $\odot 2022$ by author(s) and Open Access Library Inc.

This work is licensed under the Creative Commons Attribution International License (CC BY 4.0).

http://creativecommons.org/licenses/by/4.0/

\section{(c) (i) Open Access}

\begin{abstract}
The loss of crop production caused by weeds has become a serious threat to many important crops. The utilization of microorganism metabolites is considered as an effective method towards a wide variety of weeds in the field. In this study, sixty-eight strains were isolated from weed plants with infections symptom. Each strain was cultured in submerged liquid medium. Culture filtrate was obtained from fermented broth by filtration and it was used to determine herbicidal activity both in vitro and in vivo with two target weeds: Avena fatua and Brassica juncea. The results indicated that seven strains exhibited potent herbicidal activity against $A$. fatua and $B$. juncea and therefore chosen for secondary screening. Notably, GD-2 and PA-2 strain showed different highest toxicity to target weeds. Culture filtrate of GD-2 was most toxic to $A$. fatua while PA-2 was most toxic to $B$. juncea. Further deep study on crop safety indicated that GD-2 was least toxic to broad-bean, pea and oil rapeseed while the effects of PA-2 were varied on crop tested and range from moderate to high toxicity. Culture filtrates from both strains induce protective enzyme activity in weeds and an obvious decrease in chlorophyll content, soluble sugar and protein content. It could increase the malondialdehyde content and conductivity value. Based on the culture characteristics and the internal transcribed spacer (ITS) sequence, the GD-2 and PA-2 strain were identified as Fusarium avenaceum and Aureobacidium pullulans, respectively. Overall, two fungi strain might have potential to be developed as herbicidal agents against $A$. fatua and $B$. juncea and hope to be further applied to sustainable agriculture.
\end{abstract}

\section{Subject Areas}

Agricultural Science 


\section{Keywords}

Biological Control, Herbicidal Activity, Crop Safety, Toxicity, Identification

\section{Introduction}

Crop loss due to weeds places pressure on the production of food for human consumption. At present, the use of chemical herbicides remains the most common method in weed management strategies. However, the intensive use of chemical herbicides has increased the incidence of resistant weed population as well as risk of environmental pollution (Green and Owen, 2011 [1]; Stoate et al., 2009 [2]). Therefore, there is a growing demand for searching for new herbicide with broad-spectrum, high-efficiency, low toxicity and with new modes of action for controlling weeds in sustainable agriculture.

Biological control using microbial metabolites has attracted wide attention from researchers as an emerging method to long-term use of chemical herbicide due to their safer toxicological and environmental characteristics. Pathogenic fungi are organisms that produce a wide variety of herbicidal metabolites for agricultural application. So far, several fungal pathogens have been recorded to attack weeds throughout the world (Dagno et al., 2012) [3]. The genera Alternaria, Botrytis, Colletotrichum, Curvularia, Drechslera, Epicoccum, Exserohilum, Fusarium, Phoma, Puccinia, Pyricularia, Sclerotinia, and others have been studied intensively as bioherbicidal agents and shown to be an effective alternative to weeds prevention (Palmer et al., 2010 [4]; Friesen et al., 2008 [5]; Angélica et al., 2015 [6]).

Currently, among the reports which have been conducted on the use of the fungi to curb weeds, fungi metabolites have attracted more attention (Motlagh, 2011 [7]; Harding and Raizada, 2015 [8]). This is because they have the characteristics of high activity, selective herbicidal activity, broad spectrum and environmental compatibility. Fungal toxins are secondary metabolites that belong to different class of natural occurring compounds (Varejão et al., 2013) [9]. About two-thirds of all known natural metabolites used in agriculture and medicine are isolated from fungi. Products derived from fungal metabolites may play a very important role in the biological control of weeds. It has become increasingly difficult to find herbicides in recent years that have the ability to provide new mode of action on weed control. At this critical moment, the screening of new herbicidal fungi strains from unique biome has become a focus among the scholar in the past decade. These fungi from unique environments were found to demonstrate good herbicidal activity and safety (Daniel et al., 2018) [10].

The unique climatic conditions of Qinghai-Tibet Plateau breed a unique microbial community, many species of micro-organisms are still not identified, and applications utilizing microbial resources continue to be developed. Accordingly, the aim of this work was to identify and evaluate fungi from the Qinghai region that are able to produce molecules with herbicidal activity. According to 
this, weed plants with infecting symptoms were collected from the Qinghai region. The objectives of this study are to 1) assess the herbicidal activity of culture filtrate of fungi strains in vitro and in vivo; 2) evaluate the bio-safety of fungi in local crops; 3 ) investigate the effects of culture filtrate on the physiological and biochemical index of weeds. The results provide references for the production application of fungi based herbicides.

\section{Materials and Methods}

\subsection{Sample Collection, Pathogen Isolation and Purification}

The diseased leaf samples of weed plants were collected from agricultural areas of Qinghai region, China. The processes of fungi separation and purification were based on the protocols mentioned by Fang (1998) [11]. Briefly, the infected sections of the tissues were cut into $1.0 \times 1.0 \mathrm{~mm}$ fragments. These tissue sections were soaked in $3 \%$ sodium hypochlorite solution for $3 \mathrm{~min}$ for surface disinfection, and then rinsed 3 times with sterile water. The redundant water was removed with sterile absorbent paper towels. Each fragment was placed on potato dextrose agar (PDA) medium and cultured in a dark incubator at $25^{\circ} \mathrm{C}$. Four tissue blocks were placed on each plate. Mycelia appeared on the media surface 4 days after inoculation. The agar blocks were excised from the mycelial edges in the plates and transferred to new PDA plates for obtaining pure cultures of the fungus. The strains of fungus were coded and stored at $4^{\circ} \mathrm{C}$ for future testing.

\subsection{Submerged Fermentation}

Agar blocks from a 7-day-old fungi mycelia colony were transferred into a 500 $\mathrm{mL}$ flask with $100 \mathrm{~mL}$ of potato dextrose (PD) broth. Cultures were incubated at $25^{\circ} \mathrm{C}$ with shaking at $180 \mathrm{rpm}$ for 7 days. The culture solution of fungi strains was passed through the microporous membrane $(\Phi=0.45 \mu \mathrm{m})$ under vacuum to obtain the culture filtrate.

\subsection{Screening of Herbicidal Strains in Vitro}

Twenty-five seeds of $A$. fatua and $B$. juncea were placed on a filter paper in each of four Petri dishes each treatment, respectively. $3.0 \mathrm{~mL}$ of culture filtrate of each fungus was added to each of four Petri dishes consider as replicates. Petri dishes arranged with the same number of seeds were treated with $3.0 \mathrm{~mL}$ culture liquid and distilled water as control. Dishes were incubated at $25^{\circ} \mathrm{C}$ with photoperiod of $12 \mathrm{~h}$. The count was made on the $5^{\text {th }}$ day. The inhibition of seeds germination was measured as the percentage reduction of plumule and radicle length and germination rate in the treatment versus the germination growth in the control with sterile water. The herbicidal activities of the fungal strains were measured by the following formula (1):

Germination inhibition(\%)

$=\frac{\text { Quantity of seed germination in the control }- \text { Quantity of seed germination in the treatment }}{100}$

Quantity of seed germination in the control 


\subsection{Detached Leaf Punctured Assay}

Herbicidal activities of the culture filtrate were determined by leaf punctured assay. Detached leaves of weeds plant grown pierced using a sterile needle. Droplets $(10 \mu \mathrm{L})$ of each filtrate were applied to each of these positions (2 punctures per leaf, 3 leaves per filtrate). After drip application, the leaves were kept at $25^{\circ} \mathrm{C}$ in the sterilized moist chambers with photoperiod of $12 \mathrm{~h}$. The sterile water was used to serve as a control. The diameter of lesions and symptoms was observed after $72 \mathrm{~h}$.

\subsection{Evaluation of Herbicidal Activity of Fungi in Vivo}

Thirty milli-liter of culture filtrate was applied on 3 - 4 leaf stage weed plants. The inoculated weed plants were placed into the greenhouse at $25^{\circ} \mathrm{C}$ with photoperiod of $12 \mathrm{~h}$. Each treatment was repeated four times, and the sterile PD inoculated plants were used as controls. The following characteristics were measured: disease incidence, disease index, plant height $(\mathrm{cm})$, and fresh weight $(\mathrm{g})$. Disease incidence and index was calculated according to the previous report (Frans et al., 1987) [12]. The fresh weight was calculated for each replication using the formula (2):

$$
\begin{aligned}
& \text { The fresh weight control efficiency }(\%) \\
& =\frac{\text { Fresh weight of control }- \text { Fresh weight of treated }}{\text { Fresh weight of control }} \times 100
\end{aligned}
$$

\subsection{Safety Evaluation of Fungi Strains on Crops}

To evaluate the safety effect of fungi to crops, we selected five main cultivated crops, i.e. wheat, barley, oil rapeseed, pea and broad-bean. A volume of $30 \mathrm{~mL}$ of culture filtrate were sprayed on a pot of 3-4 leaf stage of the test crops. The same volume of sterile PD broth was used as control. Crop safety determination of each replicate was evaluated by measuring the growth inhibition rate and fresh weight inhibition rate 1 month later.

\subsection{Physiological and Biochemical Effects of Fungal Culture Filtrate on Weed Plants}

A volume of $50 \mathrm{~mL}$ of GD-2 and PA-2 culture filtrate was applied on both weeds, respectively. Control was performed using sterile water. Control and treated weed plants were kept in chambers at $25^{\circ} \mathrm{C}$ under a $12 \mathrm{~h}$ photoperiod followed by $10 \mathrm{~h}$ in the dark. Analyzed sample were gathered for each treatment at 24,48 , 72,96120 , and $144 \mathrm{~h}$ from the beginning of the exposure. Each treatment consisted of three replicates.

\subsection{Assay of Weed Defense Related Enzymes Activity}

Superoxide-dismutase (SOD) activity was measured by the means of Ahn and associates (2005) [13]. Peroxidase (POD) activity was determined with the guaiacol method (Mäkinen and Tenovuo, 1982) [14]. According to the method of He- 
gab and associates (2013) [15], catalase (CAT) activity was determined to be a decrease in absorbance at $240 \mathrm{~nm}$ due to consumption of $\mathrm{H}_{2} \mathrm{O}_{2}$. Ascorbate-peroxidase (APX) activity was determined using the procedure of Nakano and Asada (1981) [16]. Polyphenol oxidase (PPO) activity was assayed according to Inoue and associates (Inoue and Izumi, 2020) [17]. The activity of phenylalanine ammonia lyase (PAL) was determined according to the change in absorbance of trans-cinnamic acid at $290 \mathrm{~nm}$ based on the description of Hegaband associates (2013) [15].

\subsection{Determinationof Leaf Chlorophyll, Lipid Peroxidation Level, Membrane Permeability and Soluble Sugar and Protein Content}

Chlorophyll content in leaves was determined as described previously (Jiang, et al., 2008) [18]. The level of lipid peroxidation was determined based on the Malondialdehyde (MDA) content, which was measured by using the 2-thiobarbituric acid (TBA) method (Mutlu, 2011) [19]. Membrane permeability was determined as described by Hassan et al. (2014) [20]. Soluble sugar content was measured by the report describedby Gao and associates (Gao et al., 2019) [21]. Soluble protein content was determined by Coomassie Brilliant blue G-250 method (Sedmak and Grossberg, 1977) [22].

\subsection{Identification of the Strain GD-2 and PA-2}

GD-2 and PA-2 were identified by morphological and conservative gene cloning analysis. Morphological characteristics were based on the protocols described by Wei (1979) [23]. DNA was extracted from GD-2 and PA-2 mycelia by using Ezup kit (Sangon Biotech (Shanghai) Co., Ltd., China). The internal transcribed spacer (ITS) region of ribosomal RNA gene was amplified using the fungal universal primers ITS4 (5'-TCCTCCGCTTATTGATATGC-3') and ITS5

(5'-GGAAGTAAAAGTCGTAACAAGG-3'). The PCR amplification system (50 $\mu \mathrm{L})$ consisted of $4.0 \mu \mathrm{L}$ dNTP mixture $\left(2.5 \mathrm{mmol} \cdot \mathrm{L}^{-1}\right.$ each of dATP, dTTP, dCTP and dGTP), $1.0 \mu \mathrm{L}$ each of ITS4 $\left(20 \mu \mathrm{mol} \cdot \mathrm{L}^{-1}\right)$ and ITS5 $\left(20 \mu \mathrm{mol} \cdot \mathrm{L}^{-1}\right), 5.0 \mu \mathrm{L}$ of $10 \times$ Taq reaction buffer, $1.0 \mu \mathrm{L}$ Taq DNA polymerase $\left(2.5 \mathrm{U} \cdot \mu \mathrm{L}^{-1}\right), 2.0 \mu \mathrm{L}$ template DNA, and $36.0 \mu \mathrm{L}$ of $\mathrm{dd} \mathrm{H}_{2} \mathrm{O}$. PCR conditions were $94^{\circ} \mathrm{C}$ for $5 \mathrm{~min}$, followed by 35 cycles of $94^{\circ} \mathrm{C}$ for $1 \mathrm{~min}, 51^{\circ} \mathrm{C}$ for $1 \mathrm{~min}$, and $72^{\circ} \mathrm{C}$ for $1 \mathrm{~min}$; and a final extension at $72^{\circ} \mathrm{C}$ for $10 \mathrm{~min}$. After amplification, products were separated by electrophoresis on $1.0 \%$ agarose gel for $1 \mathrm{~h}$, and then the gel was stained with ethidium bromide solution $\left(0.5 \mu \mathrm{g} \cdot \mathrm{mL}^{-1}\right)$ for $15 \mathrm{~min}$. The PCR products were imaged by a Bio-Rad GelDoc 2000 imaging system, and sequenced by the Sangon Biotech (Shanghai) Co., Ltd., China. The DNA sequences were recalled by the software Chromas version 2.6.6 (Technelysium Pty Ltd., Australia). The homology of the ITS sequences was searched in the NCBI fungal DNA databases. The phylogenetic tree of GD-2 and PA-2 and related fungal species was constructed for their ITS sequences by the neighbor-joining method using MEGA 5.0 (Tamura et al. 2011) [24] and the strength of the branches of the tree was 
judged with the bootstrapping analysis method at 1000 replicates.

\subsection{Statistical Analysis}

Preliminary experimental data and charts are processed in Microsoft Excel. Data difference significance was analyzed by one-way ANOVA $(P<0.05)$ in SPSS 20 software and labeled by the alphabetic method.

\section{Results}

\subsection{Isolation and Identification of Fungi from Different Weed Plants}

In this collection, a total of 68 fungi were isolated from different weed plants in eight locations of Qinghai area. A list of fungal isolates and their sources is given in Table 1, in which fungi of different genera are isolated from different plants.

\subsection{Potential Fungi Screening for Controlling the Weeds}

To screening efficient fungi in control $A$. fatua and $B$. juncea, 68 strains from eight collection areas were rated for their potential as biocontrol agents against these two weeds by using seed germination assessment. Most fungal treatments affected the weed seeds germination with the range of from $18 \%$ to $88 \%$ (Figure 1). Mean inhibition rate of $A$. fatua was $35.2 \%$, while $B$. juncea the average inhibition rate was $36.4 \%$. Germination inhibition rate of GD-2, GD-5, XN-7, HZ-1, HZ-31, HL-1, and PA-2 ranged from $63 \%$ to $82 \%$ for A. fatua, $55 \%$ $80 \%$ for $B$. juncea. All treatments reduced $A$. fatua plumule lengths by $18.5 \%$ $87.1 \%$ and radicle lengths $20.9 \%-89.8 \%$ by of the control (Figure 2). Plumule and radicle length with PA-2 treatment were reduced by $87.1 \%$ and $89.8 \%$ for both parameters, respectively, compared with control. Reductions with GD-2 treatment were by $86.7 \%$ and $89.1 \%$ for both parameters, respectively. GD-5, XN-7, HZ-1, HZ-31, and HL-1 have also presented higher reductions on plumule and radicle length of $A$. fatua. Likewise, above treatments were the most toxic to $B$. juncea and also caused the higher reductions in seed growth (Figure 3). These seven strains GD-2, GD-5, XN-7, HZ-31, HL-1, HZ-1 and PA-2 which showed higher herbicidal activity to these two weeds in vitro were selected for next experiments.

\subsection{Detached Leaf Bioassay}

Effect on $A$. fatua leaves was more marked when the culture filtrate from GD-2 was applied (Figure 4). Maximum damage on $B$. juncea leaves was obviously observed with culture filtrate from PA-2. For GD-2 treatment, the lesions infected $80 \%$ of the leaf area. The symptoms were the yellow macula and halos of chlorosis on the surface of $A$. fatua leaves for 3 days, and formed dead zone at 5 days. For PA-2 treatment, the lesions affected $92 \%$ of the foliar area. The symptoms were brown spots and rot area on the surface of $B$. juncea leaves at 3 days and spots gradually joined into patches at 5 days. 


\subsection{Evaluation of Herbicidal Efficacy of Fungi in Greenhouse}

The highest disease incidence (86\%) of $A$. fatua was reach when the culture filtrate from GD-2 was sprayed (Table 2). Approximately $21 \%$ reduction in the height was observed for this treatment compared with the control. Significant differences were observed for the fresh weight, which ranged from 18.54 to $34.86 \mathrm{~g}$.

Table 1. Collection area, weed species collected, and number of fungi isolated in each plant.

\begin{tabular}{|c|c|c|c|}
\hline $\begin{array}{c}\text { Name of } \\
\text { collection area }\end{array}$ & Species collected & $\begin{array}{l}\text { Geographic coordinates } \\
\text { Latitude/longitude }\end{array}$ & $\begin{array}{l}\text { Number of } \\
\text { fungi isolated }\end{array}$ \\
\hline Xining (XN) & $\begin{array}{c}\text { Avena fatua } \\
\text { Melilotus suaveolens } \\
\text { Chenopodium album } \\
\text { Elsholtzia densa } \\
\text { Setaria viridis } \\
\text { Convolvulus arvensis } \\
\text { Rumex patientia }\end{array}$ & $101.75 / 36.72$ & 14 \\
\hline Guide (GD) & $\begin{array}{c}\text { Avena fatua } \\
\text { Microula sikkimensis } \\
\text { Cirsium setosum } \\
\text { Taraxacum mongolicum }\end{array}$ & $101.60 / 36.12$ & 13 \\
\hline Huangzhong (HZ) & $\begin{array}{c}\text { Avena fatua } \\
\text { Leymus secalinus } \\
\text { Cephalanoplos setosum }\end{array}$ & $101.52 / 36.47$ & 31 \\
\hline Hualong (HL) & $\begin{array}{c}\text { Avena fatua } \\
\text { Cirsium setosum } \\
\text { Melilotus suaveolens }\end{array}$ & $102.33 / 36.11$ & 2 \\
\hline Pingan (PA) & $\begin{array}{c}\text { Avena fatua } \\
\text { Populus cathayana } \\
\text { Plantago asiatica } \\
\text { Malva crispa } \\
\text { Polygonum lapathifolium } \\
\text { Brassica juncea }\end{array}$ & $102.14 / 36.52$ & 2 \\
\hline Minhe $(\mathrm{MH})$ & $\begin{array}{c}\text { Avena fatua } \\
\text { Thermopsis lanceolata }\end{array}$ & $102.94 / 36.37$ & 2 \\
\hline Datong (DT) & $\begin{array}{c}\text { Avena fatua } \\
\text { Euphorbia helioscopia }\end{array}$ & $101.83 / 37.14$ & 2 \\
\hline Jianzha (JZ) & $\begin{array}{c}\text { Avena fatua } \\
\text { Elsholtzia densa }\end{array}$ & $102.02 / 35.81$ & 2 \\
\hline
\end{tabular}



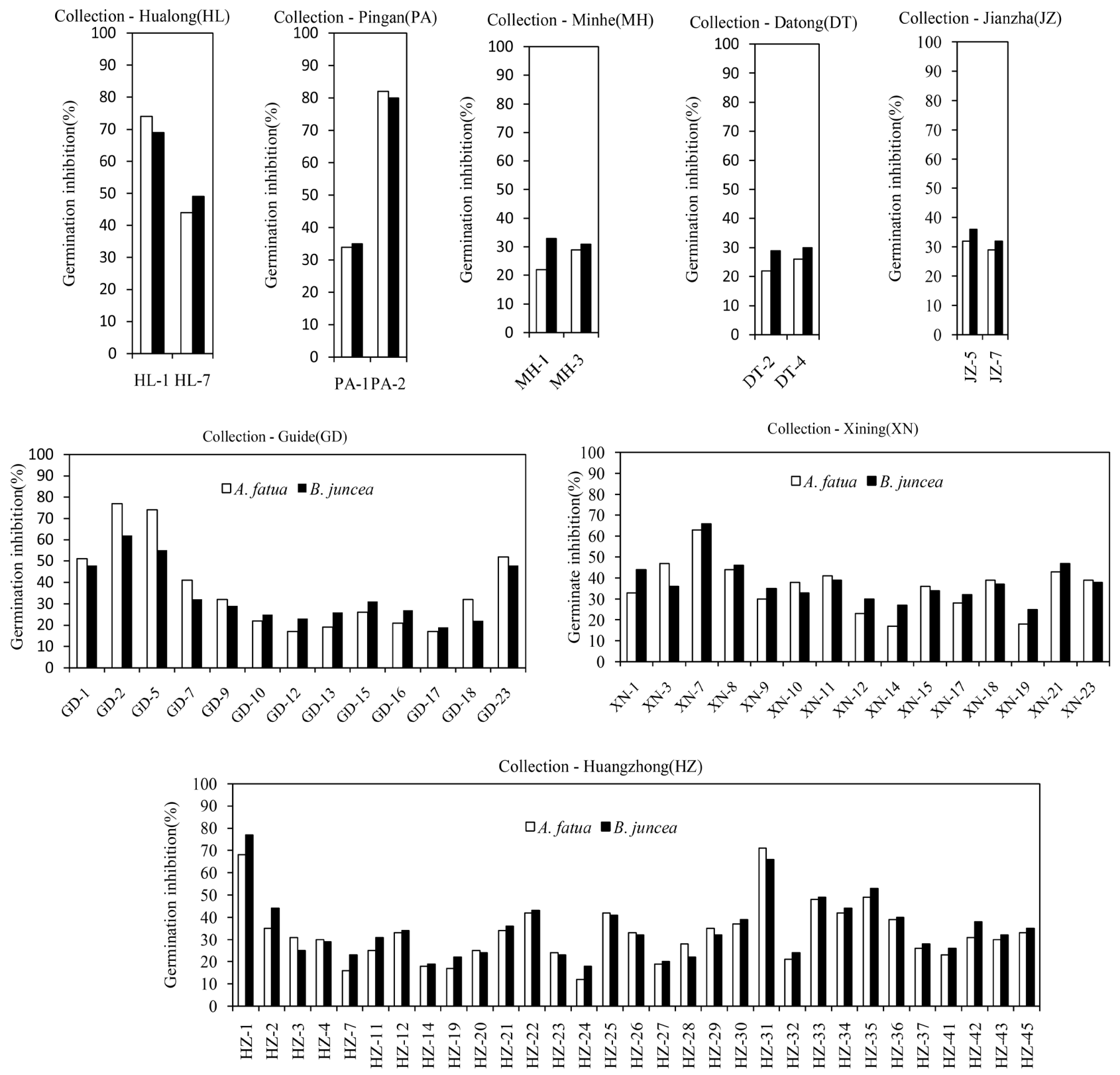

Figure 1. Effect of 68 strains on germination percentage per seedling of $A$. fatua and $B$. juncea grown in Petri-dishes at $25^{\circ} \mathrm{C}$.
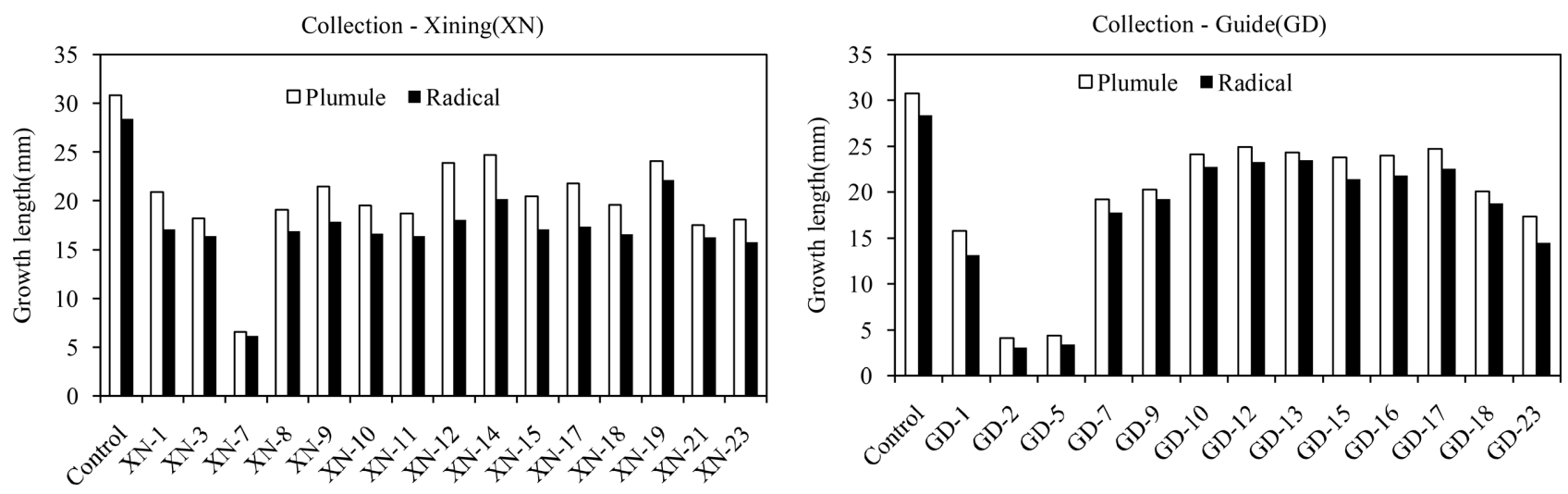

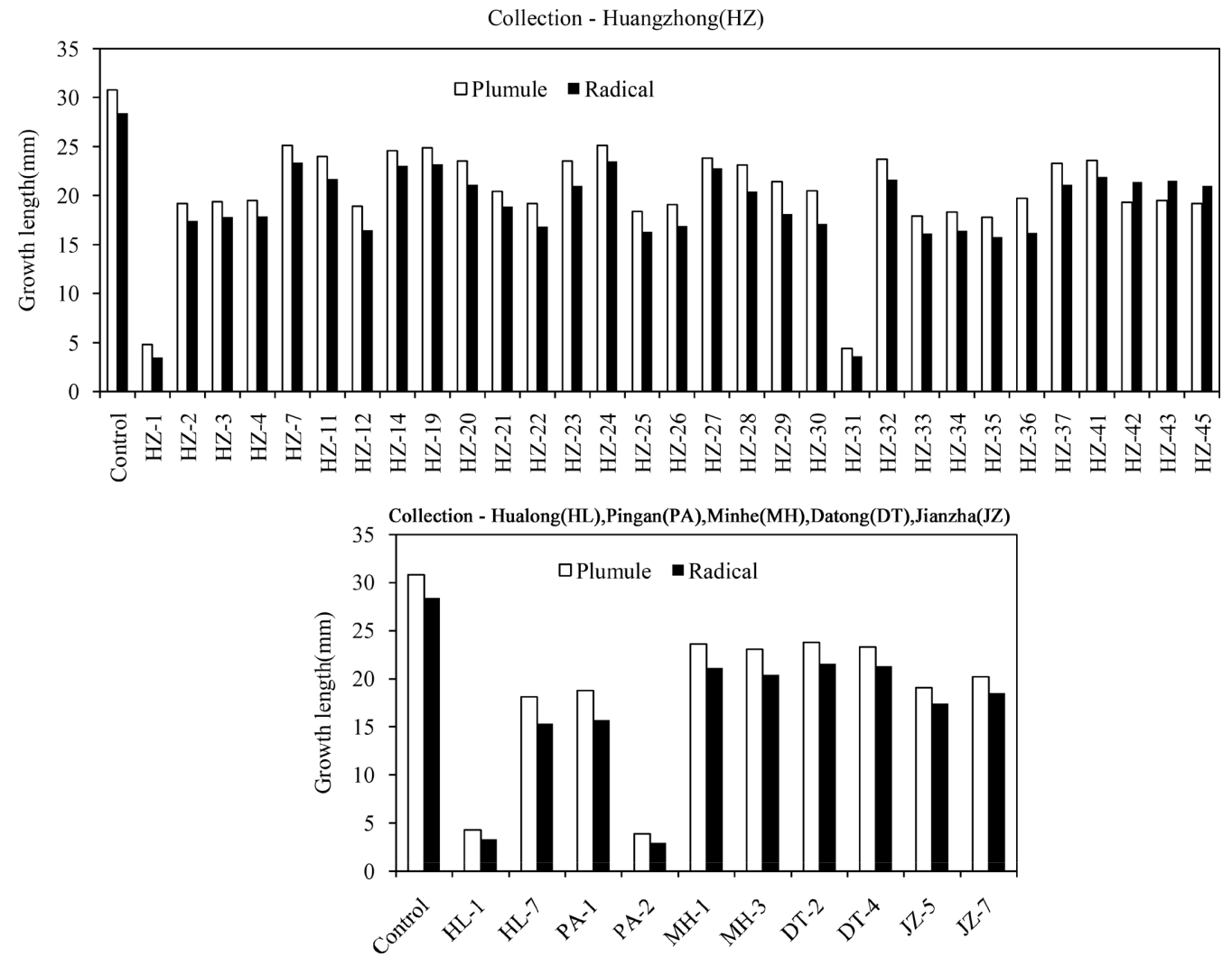

Figure 2. Effect of 68 strains on plumule length and radical length per seedling of $A$. fatua grown in Petri-dishes at $25^{\circ} \mathrm{C}$.
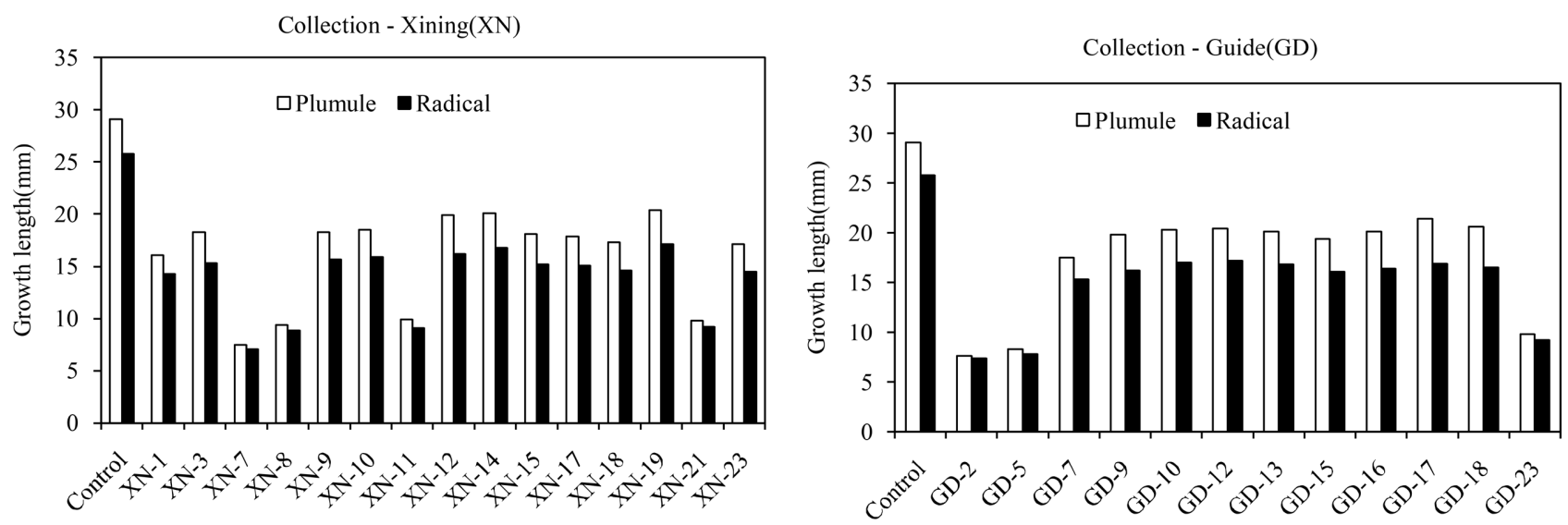

Collection - Huangzhong(HZ)

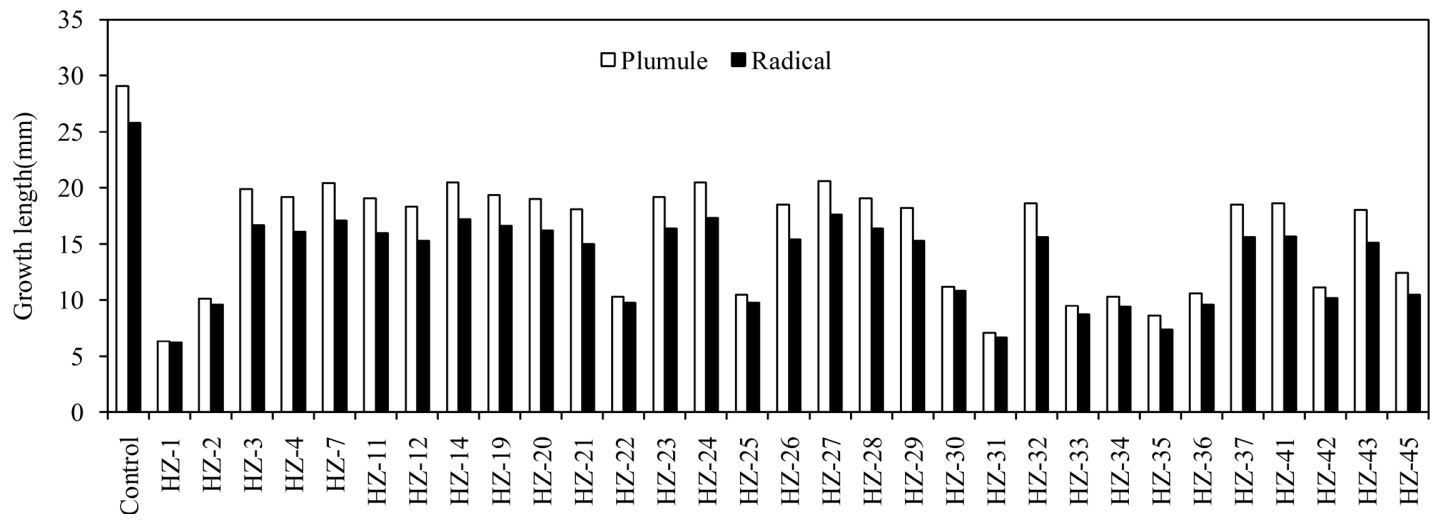




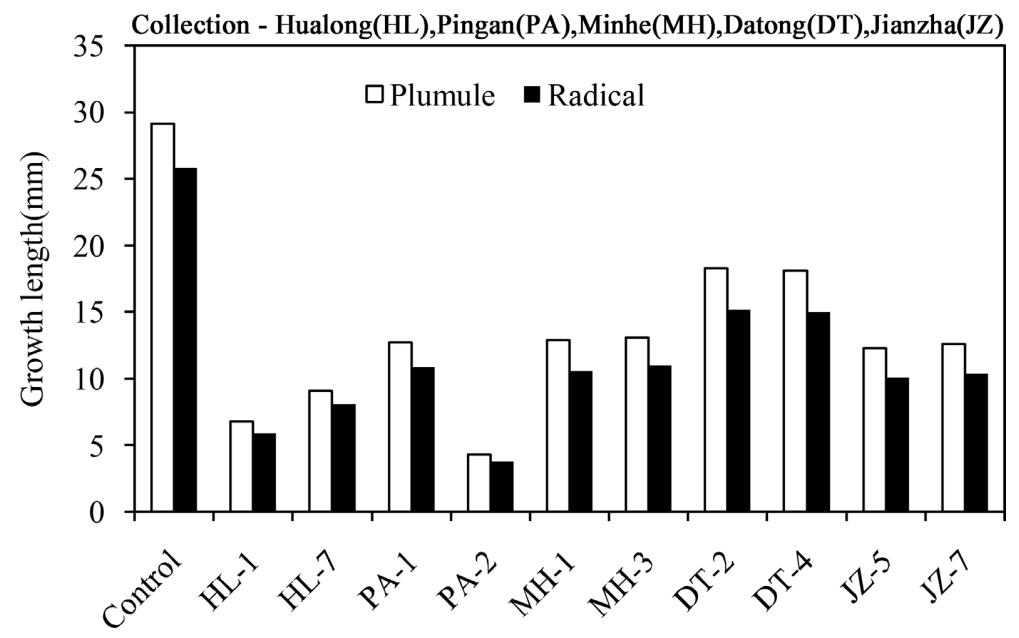

Figure 3. Effect of 68 strains on plumule length and radical length per seedling of $B$. juncea grown in Petri-dishes at $25^{\circ} \mathrm{C}$.

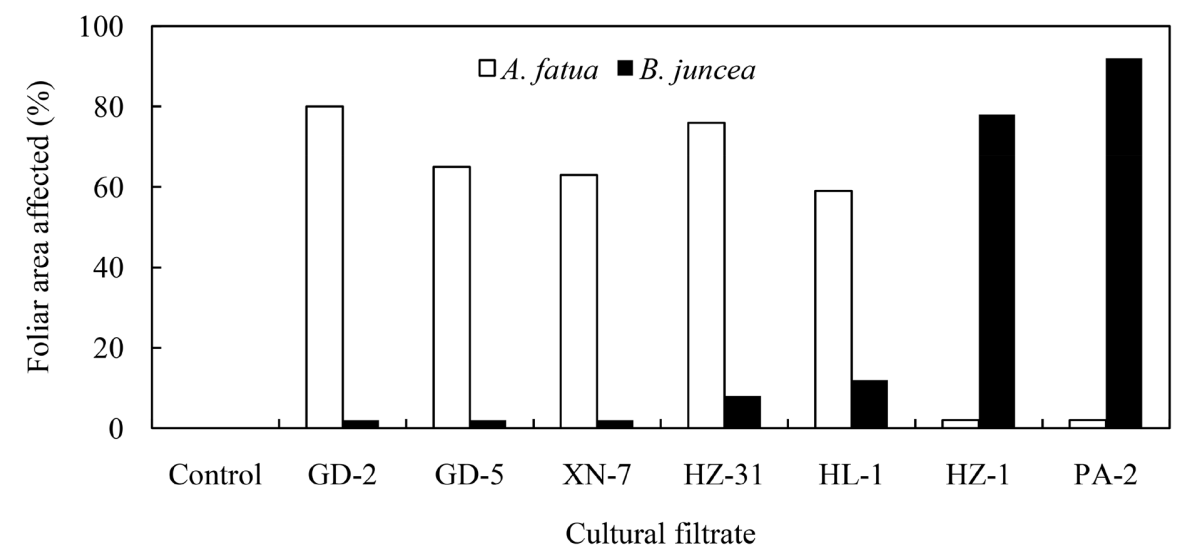

Figure 4. Phytotoxic effects of culture filtrate of 7 strains on detached leaves of $A$. fatua and B. juncea.

Table 2. Virulence of the fermentation broth of seven strains to A. fatuain vivo.

\begin{tabular}{ccccc}
\hline Treatment & $\begin{array}{c}\text { Disease incidence } \\
(\%)\end{array}$ & Disease index & $\begin{array}{c}\text { Plant height } \\
(\mathbf{c m})\end{array}$ & $\begin{array}{c}\text { Fresh weight } \\
(\mathbf{g})\end{array}$ \\
\hline Control & $0^{\mathrm{d}}$ & 0 & $21.85^{\mathrm{a}}$ & 34.86 \\
GD-2 & $86^{\mathrm{a}}$ & 84.67 & $12.35^{\mathrm{d}}$ & 18.54 \\
GD-5 & $67^{\mathrm{b}}$ & 65.00 & $14.76^{\mathrm{c}}$ & 23.57 \\
XN-7 & $71^{\mathrm{ab}}$ & 67.55 & $13.75^{\mathrm{cd}}$ & 22.97 \\
HZ-31 & $79^{\mathrm{a}}$ & 70.75 & $15.57^{\mathrm{bc}}$ & 25.85 \\
HL-1 & $83^{\mathrm{a}}$ & 75.67 & $14.85^{\mathrm{c}}$ & 24.56 \\
HZ-1 & $47^{\mathrm{c}}$ & 50.16 & $17.82^{\mathrm{b}}$ & 27.36 \\
PA-2 & $59^{\mathrm{bc}}$ & 56.57 & $16.93^{\mathrm{bc}}$ & 26.17 \\
\hline
\end{tabular}

Disease incidence of $B$. juncea ranged from $56 \%$ to $89 \%$ and was increased with PA-2 treatment by $89 \%$ compared with the control (Table 3 ). For this treatment, 
plant height was reduced by $36.55 \%$ and fresh weight by $33.76 \%$ of the control, respectively.

\subsection{Safety Evaluation of Fungi Strains on Crops}

Growth of oil rapeseed was most reduced with HZ-31 treatment and by 30.5\% of the control and followed by pea by $22.8 \%$ (Figure 5(a)). However, growth of the same crop was no significant inhibited by GD-2, GD-5, and XN-7 treatments. On the whole, culture filtrates of HZ-31, HL-1, HZ-1, and PA-2 have greater effects

Table 3. Virulence of the fermentation broth of seven strains to B. junceain vivo.

\begin{tabular}{ccccc}
\hline Treatment & $\begin{array}{c}\text { Disease incidence } \\
(\%)\end{array}$ & Disease index & $\begin{array}{c}\text { Plant height } \\
(\mathbf{c m})\end{array}$ & $\begin{array}{c}\text { Fresh weight } \\
(\mathbf{g})\end{array}$ \\
\hline Control & $0^{\mathrm{d}}$ & $0^{\mathrm{d}}$ & $17.15^{\mathrm{a}}$ & $24.35^{\mathrm{a}}$ \\
GD-2 & $56^{\mathrm{bc}}$ & $44.67^{\mathrm{c}}$ & $15.15^{\mathrm{b}}$ & $20.25^{\mathrm{b}}$ \\
GD-5 & $61^{\mathrm{b}}$ & $55.00^{\mathrm{b}}$ & $14.84^{\mathrm{b}}$ & $21.37^{\mathrm{b}}$ \\
XN-7 & $51^{\mathrm{c}}$ & $57.67^{\mathrm{b}}$ & $14.25^{\mathrm{b}}$ & $22.28^{\mathrm{a}}$ \\
HZ-31 & $72^{\mathrm{b}}$ & $60.25^{\mathrm{b}}$ & $13.57^{\mathrm{bc}}$ & $21.15^{\mathrm{b}}$ \\
HL-1 & $81^{\mathrm{a}}$ & $75.00^{\mathrm{a}}$ & $12.15^{\mathrm{c}}$ & $19.36^{\mathrm{bc}}$ \\
HZ-1 & $82^{\mathrm{a}}$ & $80.16^{\mathrm{a}}$ & $11.52^{\mathrm{c}}$ & $18.58^{\mathrm{c}}$ \\
PA-2 & $89^{\mathrm{a}}$ & $86.57^{\mathrm{a}}$ & $10.90^{\mathrm{cd}}$ & $16.13^{\mathrm{d}}$ \\
\hline
\end{tabular}
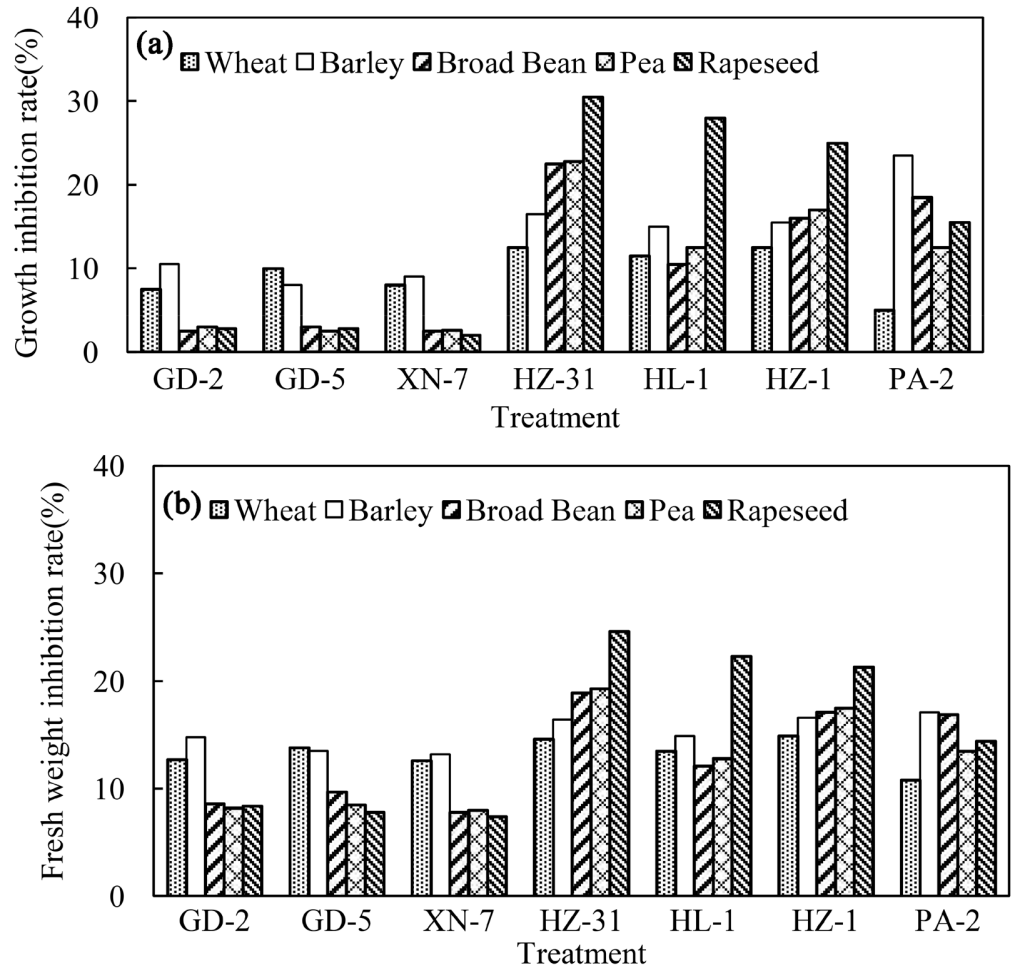

Figure 5. Effect of culture filtrates of seven fungal isolates on mean growth inhibition (a) and fresh weight inhibition (b) of five crops in Qinghai province. 
on crop growth than that of GD-2, GD-5, and XN-7. Reduction in fresh weight ranged between $7.4 \%$ and $24.6 \%$ of the control (Figure $5(\mathrm{~b})$ ). The maximum fresh weight of oil rapeseed inhibition rate $(24.6 \%)$ was reached when the culture filtrate from HZ-31 was sprayed. HL-1 culture filtrate reduced fresh weight of oil rapeseed by $22.3 \%$ and HZ-1 to oil rapeseed (21.3\%). In short, HZ-31, HL-1, HZ-1, and PA-2 were the most toxic to all tested crops, resulting in a greater fresh reductions, while GD-2, GD-5, and XN-7 were least toxic to all tested crops, especially broad-bean, pea and oil rapeseed.

\subsection{Assay of Weed Defense Related Enzymes Activity}

The activity of SOD reached its maximum in the treatment with both strains 96 $\mathrm{h}$ after inoculation (Figure 6(a)). PPO activity in the treatment with both strains was significantly lower in comparison to control throughout the experiment
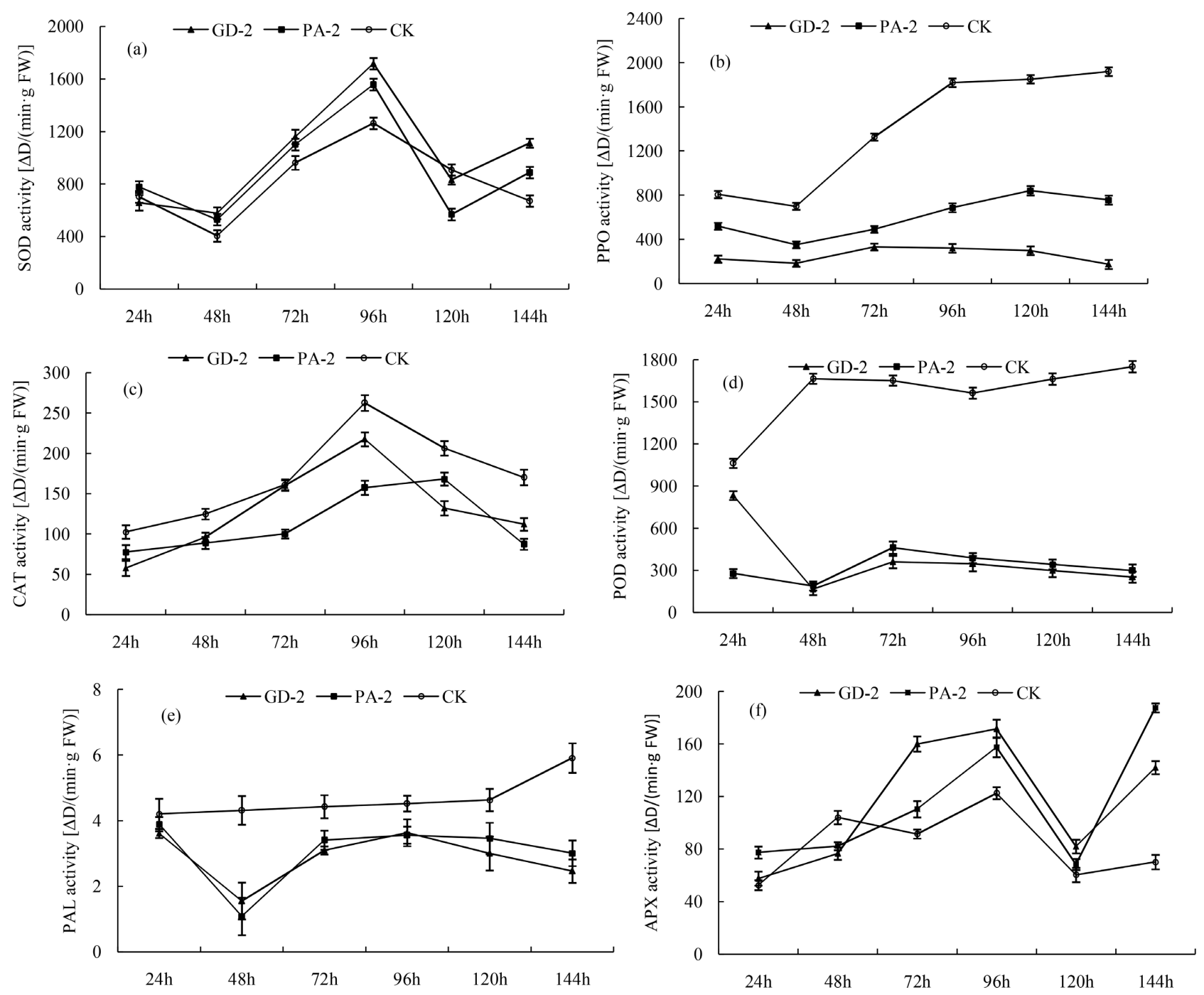

Figure 6. Effects of the culture filtrate on the activity defense-related enzyme of $A$. fatua and $B$. juncea. (a) SOD activity, (b) PPO activity, (c) CAT activity, (d) POD activity, (e) PAL activity,(f) APX activity. Data are presented as means of four replicates \pm SD, and error bar represent the standard errors of four independent treatment samples. 
(Figure 6(b)). Comparison of CAT, POD, and PAL activity at different time points indicated that the treatments had lower levels compared to control (Figures 6(c)-(e)). The highest APX activity was observed after $144 \mathrm{~h}$ of treatment when it was $102 \%$ and $167 \%$ above control, respectively (Figure 6(f)).

Generally, the chlorophyll content of both weeds decreased gradually with increase in treatment time (Table 4). Treatments resulted in a significant decrease of chlorophyll contents compared to control within $144 \mathrm{~h}$ of application. The MDA content gradually increased with increase in processing time and was reached at maximum at $144 \mathrm{~h}$ (Figure $7(\mathrm{a})$ ). There was no significant difference in MDA content between treatment and control in the early growth stages of both weeds. However, the MDA content in treatment and control was significantly difference after 48 hours of weeds treated. For relative conductivity, they were increased by using the culture filtrate and reached the highest at the $96 \mathrm{~h}$ (Figure 7(b)). As the treatment time increases, the soluble sugar content of each treatment increases accordingly (Figure 8(a)). There was no significant difference

Table 4. Effect of culture filtrate on chlorophyll content of $A$. fatua and $B$. juncea.

\begin{tabular}{|c|c|c|c|c|c|c|}
\hline & $24 \mathrm{~h}$ & $48 \mathrm{~h}$ & $72 \mathrm{~h}$ & $96 \mathrm{~h}$ & $120 \mathrm{~h}$ & $144 \mathrm{~h}$ \\
\hline \multicolumn{7}{|c|}{ Chlorophyll a contents (mg/g) } \\
\hline GD-2 & $18.17 \pm 0.12$ & $15.68 \pm 0.09$ & $14.15 \pm 0.08$ & $13.68 \pm 0.08$ & $12.18 \pm 0.05$ & $9.51 \pm 0.03$ \\
\hline PA-2 & $10.20 \pm 0.14$ & $9.17 \pm 0.05$ & $9.25 \pm 0.05$ & $7.14 \pm 0.05$ & $6.63 \pm 0.04$ & $6.16 \pm 0.02$ \\
\hline Control & $30.13 \pm 0.14$ & $30.20 \pm 0.04$ & $31.19 \pm 0.06$ & $31.16 \pm 0.12$ & $30.45 \pm 0.07$ & $30.29 \pm 1.02$ \\
\hline \multicolumn{7}{|c|}{ Chlorophyll b contents (mg/g) } \\
\hline GD-2 & $12.14 \pm 0.21$ & $10.08 \pm 0.05$ & $9.76 \pm 0.07$ & $7.48 \pm 0.06$ & $6.13 \pm 0.06$ & $5.47 \pm 0.02$ \\
\hline PA-2 & $11.67 \pm 0.19$ & $10.02 \pm 0.02$ & $8.04 \pm 0.04$ & $7.39 \pm 0.07$ & $6.07 \pm 0.05$ & $5.04 \pm 0.04$ \\
\hline Control & $23.78 \pm 0.18$ & $23.02 \pm 0.07$ & $23.11 \pm 0.11$ & $23.09 \pm 0.13$ & $23.68 \pm 0.12$ & $23.78 \pm 0.09$ \\
\hline \multicolumn{7}{|c|}{ Content of chlorophyll (mg/g) } \\
\hline GD-2 & $30.31 \pm 0.16$ & $25.76 \pm 1.04$ & $23.91 \pm 0.14$ & $21.16 \pm 0.14$ & $18.31 \pm 0.11$ & $14.98 \pm 0.03$ \\
\hline PA-2 & $21.87 \pm 0.13$ & $19.19 \pm 1.03$ & $17.29 \pm 0.16$ & $14.53 \pm 0.09$ & $12.7 \pm 0.11$ & $11.2 \pm 0.07$ \\
\hline Control & $53.91 \pm 0.19$ & $53.21 \pm 1.06$ & $54.30 \pm 0.17$ & $54.25 \pm 0.23$ & $54.13 \pm 0.18$ & $54.07 \pm 0.14$ \\
\hline
\end{tabular}
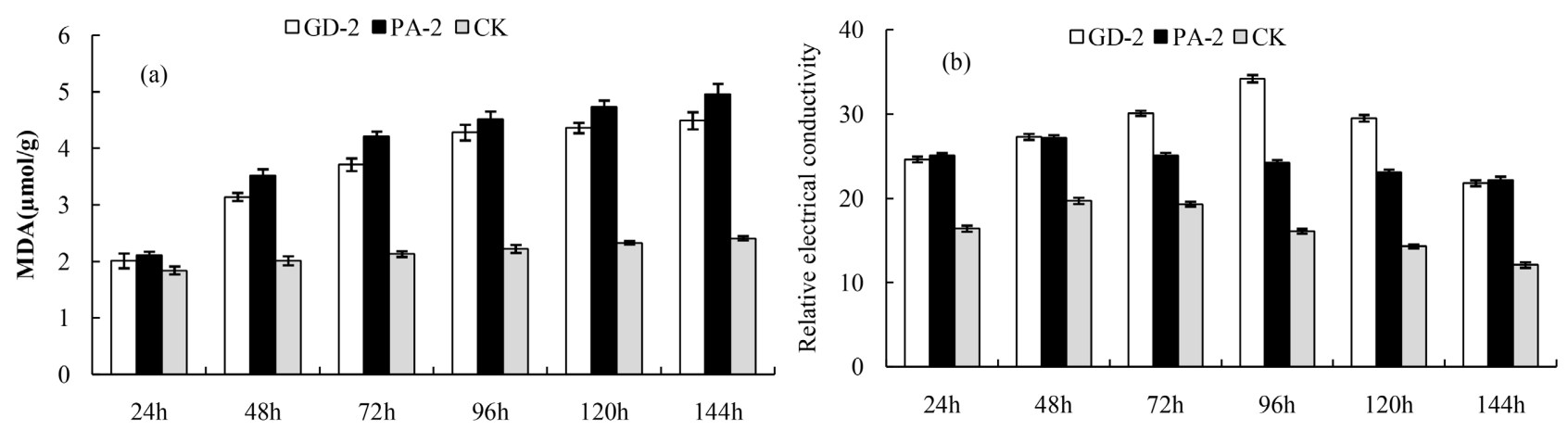

Figure 7. Effects of GD-2 and PA-2 culture filtrate on the content of MDA and the relative electrical conductivity of weed leaves. 

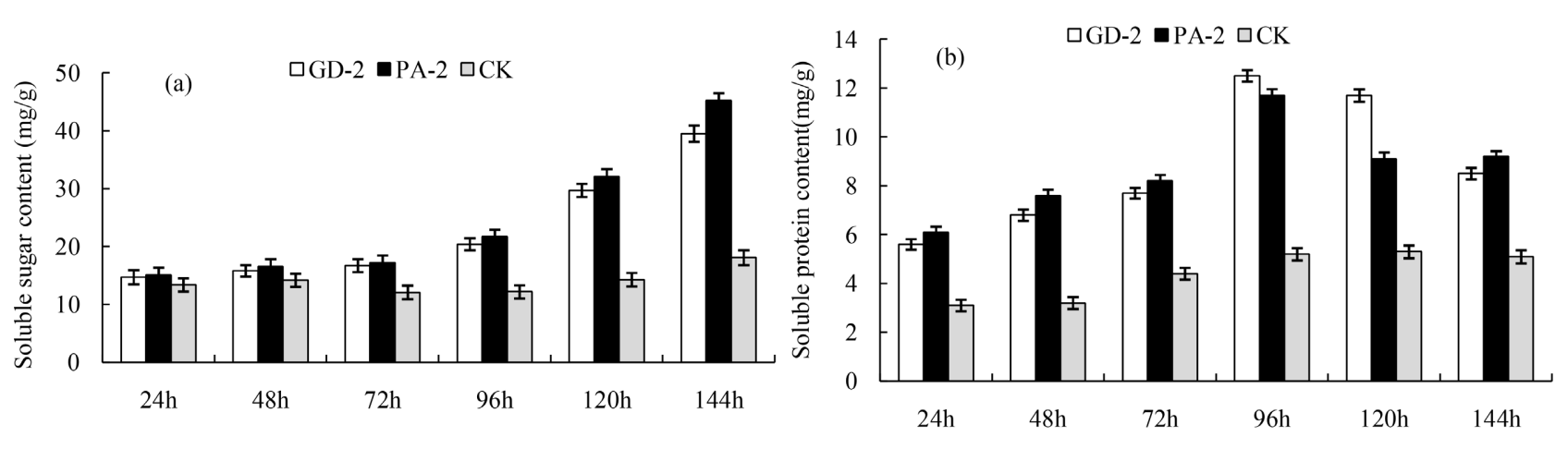

Figure 8. Effects of GD-2 and PA-2 culture filtrate on soluble sugar and protein content of weed leaves. Identification ofstrains GD-2and PA-2.

in soluble sugar content in all treatments during the early growth stages of weeds. However, after 96 hours of weed growth, the soluble sugar content in treatments was significantly higher than those in the control. The soluble protein content first showed an increase followed by a decreasing pattern (Figure 8(b)).

\subsection{Morphological Characteristics}

The centre of the GD-2 colony is slightly protruded, and the surface is cotton flocculent; the mycelium grows densely, and the surface of the substrate is amaranth, followed by an earthy yellow, the conidia are fusarium-shaped, slightly curved, tapering at both ends, 3 - 7 segregates, most of which are 3 segregated, with a size of $(24.0-70.0) \mu \mathrm{m} \times(3.5-4.0) \mu \mathrm{m}$.

The colony of PA-2 on PDA plate was dense, dirty white and viscous at the beginning and dark green around it until black, with the same positive and negative color. The edges are irregular, with obvious roots, folds, leather-like, growing close to the medium; the mycelia are black-brown, septate, rosary-like, sparsely branched and conidia are conidial; the mycelia in the base are developed, and the aerial hyphae is undeveloped and not easy to pick.

\subsection{Molecular Identification}

$538 \mathrm{bp}$ and $560 \mathrm{bp}$ fragment of the ITS region from the genomic DNA of GD-2 and PA-2 was amplified with the fungal ITS primers, respectively. The phylogenetic tree constructed with the ITS sequences from GD-2, other strains of $F$. avenaceum and other related fungal species showed that GD-2 belongs to a clade with three strains of $F$. avenaceum (KY272780.1, KY272764.1, EU255801.1) supported by a $100 \%$ bootstrap value. Similarly, PA-2 belongs to a clade with seven strains of $A$. pullulans supported by a $100 \%$ bootstrap value. Based on the morphological characteristics and ITS sequences, the strain GD-2 and PA-2 was identified as F. avenaceum and A. pullulans, respectively (Figure 9).

\section{Discussion}

In this study, we have figured out that two fungicould act as two potential and efficient biocontrol agents, and $F$. avenaceum GD-2 and $A$. pullulans PA-2 were 


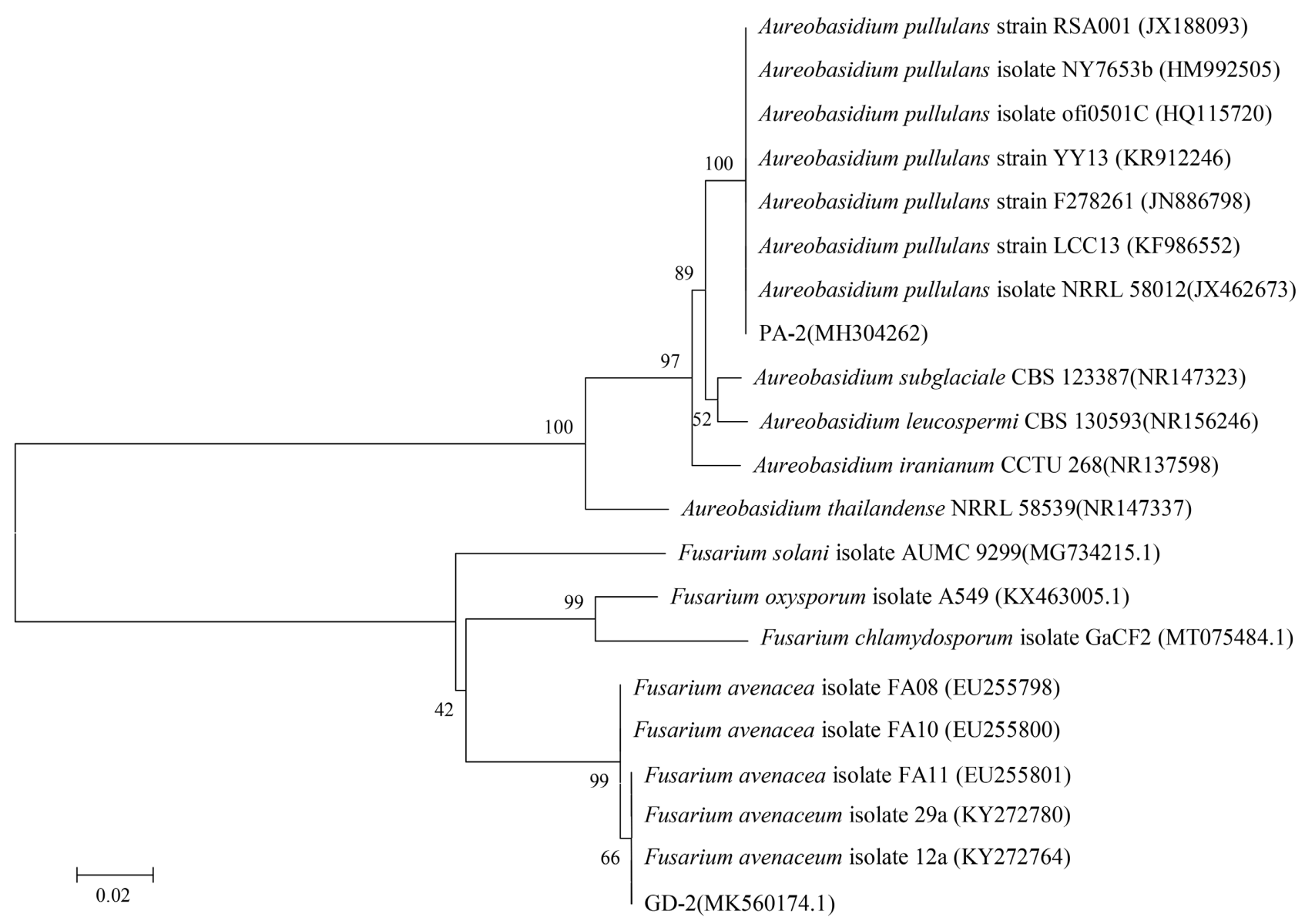

Figure 9. Phylogenetic tree of strain GD-2 and PA-2 based on ITS rDNA.

screened out with high herbicidal activity, which could significantly control $A$. fatua and $B$. juncea, respectively. Fusarium spp. was ubiquitous in nature because of its low cost, long-lasting benefits, and the ability to better adapt to various harsh environments. Many authors have isolated Fusarium spp. and used it forthe integrated weeds management (Tan et al., 2002 [25]; Tiourebaev et al., 2001 [26]; Ndambi et al., 2012 [27]).

For example, Jair and associates reported that F. fujikuroi could be use for Cucumis sativus and Sorghum bicolor controlling in the greenhouse (Daniel et al., 2018) [9]. Pearson mentioned that four kind of Fusarium spp., which was isolated from Jacobaea vulgaris, show to be herbicidal activity of seedlings growth of ragwort (Pearson et al., 2016) [28]. Aybeke (2017) [29] showed that F. oxysporum had significantly inhibitory effects against important parasitic weed (Orobanche spp.). $\mathrm{Li}$ (2014) [30] confirmed that the fermentation filtrate of F. proliferatum exhibited selective herbicidal activity against the seed germination of Amaranthus retroflexus. However, there have been no literatures on the control of weeds by $A$. pullulans so far. Thus, this is the first report on the herbicidal activity of $A$. pullulans as a source of metabolites.

In the process of screening biocontrol agents, it is critical to establish a suitable screening system (You et al., 2013) [31]. In this study, the herbicidal activities 
of fungi against weed plants were evaluated in vivo and in vitro. The herbicidal effects of GD-2 and PA-2 both on the seed germination and detached leaf of $A$. fatua and $B$. juncea were stronger than other isolates in vitro. But bioassay in vitro cannot always represent in herbicidal activity on both weeds. Our results further demonstrated that both isolates can significantly reduce the growth of both kinds of weeds under greenhouse conditions. In addition, crop safety results showed in vivo GD-2 exhibited little inhibitory effect on plant height and fresh weight on crop tested when compare with other fungi. The effects of PA-2 were varied on crop tested and range from moderate to high toxicity. Although PA-2 caused a few slight flecks on the plants of monocotyledons crops, it did not inhibit the crop growth over time. Though further assessments are needed in the field experiments, the selective herbicidal activity could have practical applications as herbicidal agents.

Changes in defense enzymes are often used as indicators of plant responses to stress. In this work, most protective enzyme activities in both weeds initially increased, but then reduced with more time treating, indicating that adverse stress was unfavorable for weeds growth and cause fluctuations of protective enzyme activity. The results in this work also displayed that the contents of chlorophyll of the two weed plants were found to be much lower compared to control after treatments. The lower values of chlorophyll with treatment indicated that culture filtrate inhibits chlorophyll synthesis; thereby reduce the growth and development of weed plants. This is consistent with the results of Olle et al. (2013) [32] and Radhakrishnan et al. (2016) [33], which indicated that culture filtrates inhibits plant growth by suppressing the synthesis of chlorophyllin both weeds. With the culture filtrate treatment, MDA content and electrical conductivity increased indicating that stress can increase the permeability of plant membranes. Our study is consistent with the previous reports that culture filtrates can increase MDA content and electrical conductivity (Gao et al., 2019) [21]. Soluble sugars play an important role in the stabilization of plant cell membranes and protoplasm. In this work, the treatment time was proportional to the soluble sugar content, which is consistent with previous studies (Gao et al., 2019) [21]. Soluble protein content is one of the important indicators of plant metabolism or photosynthetic products. We found that the soluble protein content of the two weeds increased first and then gradually decreased with the increase of treatment time, and reached the highest value at $144 \mathrm{~h}$.

For the molecular identification, several study have explored the limitations and insufficiency of ITS in identifying complex and variable genes of subspecies and varieties of fungi, and suggested more additional gene sequences, such as intergenic spacer (IGS), translation elongation factor $1 \alpha$ (TEF-1 $\alpha$ ) and so on, be included for the species differentiation (Nilsson et al., 2008) [34]. However, with the application of high-throughput technologies, other studies have discovered that the ITS region is very effective in differentiating subspecies, and varieties (Badotti et al., 2017) [35]. In this study, ITS sequence data analysis combined 
with traditional morphological provides sufficient resolution to reliably detect and identify Fusarium and Aureobasidium species.

\section{Conclusion}

In total, a total of 68 fungi were isolated from weed plants for evaluation of the potential for herbicidal activity. In the initial screening, 7 strains were selected for evaluation of act in detached leaf puncture and greenhouse assays. In these assays, the fungi coded GD-2 and PA-2 provided the most predicted result, and identified as $F$. avenaceum and A. pullulans. Culture filtrates from GD-2 and PA-2 exhibited $86 \%$ and $89 \%$ of disease incidence against $A$. fatua and $B$. juncea, respectively. The plant height and fresh weight of $A$. fatua decreased by $43 \%$ and $47 \%$, respectively, while that of $B$. juncea decreased by $36 \%$ and $34 \%$, respectively. Culture filtrates from GD-2 and PA-2 showed selective toxicity to weeds leaves and crops tested. Under the culture filtrates stress, chlorophyll content, soluble sugar and protein content of weed plants changed significantly. These results provided theoretical basis for the development of biological herbicides for these two strains in the next step.

\section{Acknowledgements}

This work was supported by the National Natural Science Foundation of China (Grant No. 31760539), the Key Laboratory Project on Agricultural Integrated Pest Management of Qinghai Province (Grant No.2021-ZJ-Y08), and the second Tibetan Plateau Scientific Expedition and Research Program (Grant No. 2019QZKK0303).

\section{Conflicts of Interest}

The authors declare no conflicts of interest.

\section{References}

[1] Green, J.M. and Owen, M.D.K. (2011) Herbicide-Resistant Crops: Utilities and Limitations for Herbicide-Resistant Weed Management. Journal of Agricultural and Food Chemistry, 59, 5819-5829. https://doi.org/10.1021/jf101286h

[2] Stoate, C., Baldi, A., Beja, P., Boatman, N.D., et al. (2009) Ecological Impacts of Early 21st Century Agricultural Change in Europe-A Review. Journal of Environmental Management, 91, 22-46. https://doi.org/10.1016/j.jenvman.2009.07.005

[3] Dagno, K., Lahlali, R., Diourté, M. and Jijakli, M.H. (2012) Present Status of the Development of Mycoherbicides against Water Hyacinth: Successes and Challenges. A Review. Biotechnology, Agronomy and Society and Environment, 16, 360-368. https://doi.org/10.1080/09064710.2012.687054

[4] Palmer, W.A., Heard, T.A. and Sheppard, A.W. (2010) A Review of Australian Classical Biological Control of Weeds Programs and Research Activities over the Past 12 Years. Biological Control, 5, 271-287. https://doi.org/10.1016/j.biocontrol.2009.07.011

[5] Friesen, T.L., Faris, J.D., Solomon, P.S. and Oliver, R.P. (2008) Host-Specific Toxins: Effectors of Necrotrophic Pathogenicity. Cellular Microbiology, 10, 1421-1428. 
https://doi.org/10.1111/j.1462-5822.2008.01153.x

[6] Angélica, R.C., Daiana, B.B., Jessica, L., Vitória, P., Camila, M., Rafael, C.F., Raquel, C.K., Rodrigo, J.S. and Ash, G.J. (2010) The Science, Art and Business of Successful Bioherbicides. Biological Control, 52, 230-240.

https://doi.org/10.1016/j.biocontrol.2009.08.007

[7] Motlagh, M.R.S. (2011) Evaluation of Epicoccum purpurascens as Biological Control Agent of Echinochloa spp. in Rice Fields. Journal of Food Agriculture and Environment, 9, 394-397.

[8] Harding, D.P. and Raizada, M.N. (2015) Controlling Weeds with Fungi, Bacteria and Viruses: A Review. Frontiers in Plant Science, 6, Article No. 659. https://doi.org/10.3389/fpls.2015.00659

[9] Daniel, J.J., Zabot, G.L., Tres, M.V., Harakava, R., Kuhn, R.C. and Mazutti, M.A. (2018) Fusarium Fujikueor: A Novel Source of Metabolites with Herbicidal Activity. Biocatalysis and Agricultural Biotechnology, 14, 314-320.

https://doi.org/10.1016/j.bcab.2018.04.001

[10] Varejão, E.V.V., Demuner, A.J., Barbosa, A. and Barreto, R.W. (2013) The Search for New Natural Herbicides-Strategic Approaches for Discovering Fungal Phytotoxins. Crop Protection, 48, 41-50. https://doi.org/10.1016/j.cropro.2013.02.008

[11] Fang, Z.D. (1998) Study Methods of Plant Pathology. China Agriculture Press, Beijing.

[12] Frans, R., Talbert, R., Marx, D. and Crowley, H. (1986) Experimental Design and Techniques for Measuring and Analyzing Plant Responses to Weed Control Practices. In: Camper, N.D., Ed., Research Methods in Weed Science, 3rd Edition, Southern Weed Science Society, Champaign, 29-46.

[13] Ahn, B., Paulitz, T., Jabaji-Hare, S. and Watson, A.K. (2005) Enhancement of Colletotrichum coccodes Virulence by Inhibitors of Plant Defense Mechanisms. Biocontrol Science and Technology, 15, 299-308. https://doi.org/10.1080/09583150400016977

[14] Mäkinen, K.K. and Tenovuo, J. (1982) Observations on the Use of Guaiacol and 2,2'-Azino-di(3-ethylbenzthiazoline-6-sulfonic acid) as Peroxidase Substrates. Analytical Biochemistry, 126, 100-108. https://doi.org/10.1016/0003-2697(82)90114-2

[15] Hegab, M.M., Abdelgawad, H., Abdelhamed, M.S., Hammouda, O., Pandey, R., Kumar, V. and Zinta, G. (2013) Effects of Tricin Isolated from Jungle Rice (Echinochloa colona L.) on Amylase Activity and Oxidative Stress in Wildoat (Avena fatua L.). Allelopathy Journal, 31, 345-354. https://doi.org/10.1080/00103624.2012.756003

[16] Nakano, Y. and Asada, K. (1981) Hydrogen Peroxide Is Scavenged by Ascorbate-Specific Peroxidase in Spinach Chloroplasts. Plant and Cell Physiology, 22, 867-880. https://doi.org/10.1093/oxfordjournals.pcp.a076232

[17] Inoue, A. and Izumi, H. (2020) Influence of Artificial Inoculation with Pseudomonas fluorescens on Enzymatic Browning Reactions of Fresh-Cut Potatoes. Biocontrol Science, 25, 215-222. https://doi.org/10.4265/bio.25.215

[18] Jiang, S.J., Qiang, S., Zhu, Y.Z. and Dong, Y.F. (2008) Isolation and Phytotoxicity of a Metabolite from Curvularia eragrostidis and Characterisation of Its Modes of Action. Annals of Applied Biology, 152, 103-111. https://doi.org/10.1111/j.1744-7348.2007.00202.x

[19] Mutlu, S., Atici, O., Esim, N. and Mete, E. (2011) Essential Oils of Catmint (Nepeta meyeri Benth.) Induce Oxidative Stress in Early Seedlings of Various Weed Species. Acta Physiologiae Plantarum, 33, 943-951. 
https://doi.org/10.1007/s11738-010-0626-3

[20] Hassan, M.O., Gomaa, N.H., Fahmy, G.M., Gonzalez, L., Hammouda, O. and Atteya, A.M. (2014) Influence of Sonchus oleraceus L. Residue on Soil Properties and Growth of Some Plants. The Philippine Agricultural Scientist, 97, 368-376.

[21] Gao, Z., Khalid, M., Jan, F., Saeed-ur-Rahman, Jiang, X. and Yu, X. (2019) Effects of Light-Regulation and Intensity on the Growth, Physiological and Biochemical Properties of Aralia elata (miq.) Seedlings. South African Journal of Botany, 121, 456-462. https://doi.org/10.1016/j.sajb.2018.12.008

[22] Sedmak, J.J. and Grossberg, S.E. (1977) A Rapid, Sensitive, and Versatile Assay for Protein Using Coomassie Brilliant Blue G250. Analytical Biochemistry, 79, 544-552. https://doi.org/10.1016/0003-2697(77)90428-6

[23] Wei, J.C. (1979) Fungal Identification Manual. Science and Technology Press, Shanghai, 172-270.

[24] Tamura, K., Stecher, G., Peterson, D., Filipski, A. and Kumar, S. (2013) MEGA6: Molecular Evolutionary Genetics Analysis Version 6.0. Molecular Biology and Evolution, 30, 2725-2729. https://doi.org/10.1093/molbev/mst197

[25] Tan, W.A., Li, Q.J. and Qing, L. (2002) Biological Control of Alligatorweed (Alternanthera philoxeroides) with a Fusarium sp. Biological Control, 47, 463-479. https://doi.org/10.1023/A:1015606224100

[26] Tiourebaev, K.S., Semenchenko, G.V., Dolgovskaya, M., McCarthy, M.K., Anderson, T.W., Carsten-Conner, L.D., Pilgeram, A.L. and Sands, D.C. (2001) Biological Control of Infestations of Ditchweed (Cannabis sativa) with Fusarium oxysporum $\mathrm{f}$. sp. cannabis in Kazakhstan. Biocontrol Science and Technology, 11, 535-540. https://doi.org/10.1080/09583150120067562

[27] Ndambi, B., Cadisch, G., Elzein, A. and Heller, A. (2012) Tissue Specific Reactions of Sorghum Roots to the Mycoherbicide F. oxysporum f. sp. strigae versus the $\mathrm{Pa}$ thogenic F. ptoliferatum. Biocontrol Science and Technology, 22, 135-150. https://doi.org/10.1080/09583157.2011.644760

[28] Pearson, K.A., Taylor, A.F.S. and Fuchs, R.M.E. (2016) Characterisation and Pathogenicity of Fusarium Taxa Isolated from Ragwort (Jacobaea vulgaris) Roots. Fungal Ecology, 20, 186-192. https://doi.org/10.1016/j.funeco.2015.12.011

[29] Aybeke, M. (2017) Fusarium Infection Causes Genotoxic Disorders and Antioxidant-Based Damages in Orobanche spp. Microbiological Research, 201, 46-51. https://doi.org/10.1016/j.micres.2017.05.001

[30] Li, S., Shao, M.W., Lu, Y.H., Kong, L.C., Jiang, D.H. and Zhang, Y.L. (2014) Phytotoxic and Antibacterial Metabolites from Fusarium proliferatum ZS07 Isolated from the Gut of Long-Horned Grasshoppers. Journal of Agricultural and Food Chemistry, 62, 8997-9001. https://doi.org/10.1021/jf502484n

[31] You, J.Q., Zhang, J., Wu, M.D., Yang, L., Chen, W.D. and Li, G.Q. (2016) Multiple Criteria-Based Screening of Trichoderma Isolated for Biological Control of Botrytis cinerea on Tomato. Biological Control, 101, 31-38.

https://doi.org/10.1016/j.biocontrol.2016.06.006

[32] Olle, M. and Viršile, A. (2013) The Effects of Light-Emitting Diode Lighting on Greenhouse Plant Growth and Quality. Agricultural and Food Science, 22, 223-234. https://doi.org/10.23986/afsci.7897

[33] Radhakrishnan, R., Park, J.M. and Lee, I.J. (2016) Enterobacter sp. I-3, a Bio-Herbicide Inhibits Gibberellins Biosynthetic Pathway and Regulates Abscisic Acid and Amino Acids Synthesis to Control Plant Growth. Microbiological Research, 193, 132-139. 
https://doi.org/10.1016/j.micres.2016.10.004

[34] Nilsson, R.H., Kristiansson, E., Ryberg, M., Hallenberg, N. and Larsson, K.H. (2008) Intraspecific ITS Variability in the Kingdom Fungi as Expressed in the International Sequence Databases and Its Implication for Molecular Species Identification. Evolutionary Bioinformatics, 4, 193-201. https://doi.org/10.4137/EBO.S653

[35] Badotti, F., Francislon, S.O., Garcia, C.F., Aline, B.M.V., Fonseca, P.L.C., Nahum, L.A., Oliveira, G. and Góes-Neto, A. (2017) Effectiveness of ITS and Sub-Regions as DNA Barcode Markers for the Identification of Basidiomycota (Fungi). BMC Microbiology, 17, Article No. 42. https://doi.org/10.1186/s12866-017-0958-x 